\title{
Stable isotope and fatty acid analyses reveal significant differences in trophic niches of Smooth Hammerhead Sphyrna zygaena (Carcharhiniformes) among three nursery areas in northern Humboldt Current System
}

\author{
Eduardo Segura-Cobeña ${ }^{\text {Corresp., Equal first author, } 1,2}$, Joanna Alfaro-Shigueto ${ }^{2,3}$, Jeffrey Mangel ${ }^{2,4}$, Angel Urzua ${ }^{5,6}$, Konrad \\ Górski ${ }^{\text {Corresp. Equal first author, 5, 6,7 }}$ \\ 1 Programa de Magister en Ecología Marina, Facultad de Ciencias, Universidad Católica de la Santísima Concepción, Concepción, Chile \\ 2 ProDelphinus, Lima, Perú \\ 3 Carrera de Biología Marina, Facultad de Ciencias Veterinarias y Biológicas, Universidad Cientifica del Sur, Lima, Perú \\ ${ }^{4}$ Centre for Ecology and Conservation, School of Biosciences, Cornwall Campus, University of Exeter, Penryn, Cornwall, United Kingdom \\ 5 Departamento de Ecología, Facultad de Ciencias, Universidad Católica de la Santísima Concepción, Concepción, Chile \\ ${ }^{6}$ Centro de Investigación en Biodiversidad y Ambientes Sustentables (CIBAS), Universidad Católica de la Santísima Concepción, Concepción, Chile \\ 7 Instituto de Ciencias Marinas y Limnológicas, Facultad de Ciencias, Universidad Austral de Chile, Valdivia, Chile \\ Corresponding Authors: Eduardo Segura-Cobeña, Konrad Górski \\ Email address: esegura@magister.ucsc.cl, konrad.gorski@uach.cl
}

Fishery pressure on nursery areas of smooth hammerhead in northern Peruvian coast have become a serious threat to sustainability of this resource. Even though, some management actions focused on conservation of the smooth hammerhead populations were proposed in recent years, their scientific foundations are often limited, and biomass of smooth hammerhead in Peruvian waters continues to decrease. To inform management and conservation, this study aims to evaluate the trophic niche of smooth hammerhead juveniles from three nursery areas in northern Peruvian coast using stable isotope and fatty acid analyses. First, we compared the environmental characteristics of each nursery area (i.e. sea surface temperature and chlorophyll-a concentration) and concluded that nursery areas differed significantly and consistently in sea surface temperature. Subsequently, we evaluated isotopic composition of carbon and nitrogen and fatty acid profiles of muscle and liver tissues collected from juvenile smooth hammerhead from each nursery area. We found that juvenile smooth hammerhead captured in San José were enriched in heavier ${ }^{13} \mathrm{C}$ and ${ }^{15} \mathrm{~N}$ isotopes compared to those captured in Máncora and Salaverry. Furthermore, the broadest isotopic niches were observed in juveniles from Máncora, whereas isotopic niches of juveniles from Salaverry and San José were narrower. This difference is primarily driven by the Humboldt Current System and associated upwelling of cold and nutrient rich water that drives increased primary production in San José and, to a less extent, in Salaverry. Compared to smooth hammerhead juveniles from PeerJ reviewing PDF | (2020:11:55838:1:1:NEW 1 Mar 2021) 
Máncora, those from San José and Salaverry were characterised by higher essential fatty acid concentrations related to pelagic and migratory prey. We conclude that smooth hammerhead juveniles from three nursery areas in northern Peruvian coast differ significantly in their trophic niches. Thus, management and conservation efforts should consider each nursery area as a unique juvenile stock associated with a unique ecosystem and recognize the dependence of smooth hammerhead recruitment in San José and Salaverry on the productivity driven by the Humboldt Current System. 
1 Stable isotope and fatty acid analyses reveal significant differences in trophic niches of Smooth

2 Hammerhead Sphyrna zygaena (Carcharhiniformes) among three nursery areas in northern Humboldt

3 Current System

4 Eduardo Segura-Cobeña ${ }^{1,2}$, Joanna Alfaro-Shigueto2,3, Jeffrey Mangel ${ }^{2,4}$, Ángel Urzúa ${ }^{5,6}$, Konrad Górski ${ }^{5,6,7}$

$5{ }^{1}$ Programa de Magister en Ecología Marina, Facultad de Ciencias, Universidad Católica de la Santísima

6 Concepción, Alonso de Ribera 2850, Concepción, Chile.

72 ProDelphinus, José Gálvez 780-E, Lima 18, Perú.

$8{ }^{3}$ Carrera de Biología Marina, Facultad de Ciencias Veterinarias y Biológicas, Universidad Científica del

9 Sur, Panamericana Sur, Km 19, Lima, Perú.

$10{ }^{4}$ Centre for Ecology and Conservation, School of Biosciences, University of Exeter, Cornwall Campus,

11 Penryn, Cornwall TR10 9EZ, United Kingdom.

$12{ }^{5}$ Departamento de Ecología, Facultad de Ciencias, Universidad Católica de la Santísima Concepción,

13 Alonso de Ribera 2850, Concepción, Chile

$14{ }^{6}$ Centro de Investigación en Biodiversidad y Ambientes Sustentables (CIBAS), Universidad Católica de la

15 Santísima Concepción, Alonso de Ribera 2850, Concepción, Chile

$16{ }^{7}$ Instituto de Ciencias Marinas y Limnológicas, Facultad de Ciencias, Universidad Austral de Chile,

17 Campus Isla Teja S/N, Valdivia, Chile

18 Corresponding authors:

19 Eduardo Segura-Cobeña ${ }^{1,2}$

20 El Mañio 242, Talcahuano, Concepción, Biobío, 4030000, Chile

21 Email: esegura@magister.ucsc.cl

22 Konrad Górski ${ }^{5,6,7}$

23 Los Raulíes 415, Valdivia, Los Ríos, 5090000, Chile

24 Email: konrad.gorski@uach.cl 


\section{Abstract}

Fishery pressure on nursery areas of smooth hammerhead in northern Peruvian coast have become a serious threat to sustainability of this resource. Even though, some management actions focused on conservation of the smooth hammerhead populations were proposed in recent years, their scientific foundations are often limited, and biomass of smooth hammerhead in Peruvian waters continues to decrease. To inform management and conservation, this study aims to evaluate the trophic niche of smooth hammerhead juveniles from three nursery areas in northern Peruvian coast using stable isotope and fatty acid analyses. First, we compared the environmental characteristics of each nursery area (i.e. sea surface temperature and chlorophyll-a concentration) and concluded that nursery areas differed significantly and consistently in sea surface temperature. Subsequently, we evaluated isotopic composition of carbon and nitrogen and fatty acid profiles of muscle and liver tissues collected from juvenile smooth hammerhead from each nursery area. We found that juvenile smooth hammerhead captured in San José were enriched in heavier ${ }^{13} \mathrm{C}$ and ${ }^{15} \mathrm{~N}$ isotopes compared to those captured in Máncora and Salaverry. Furthermore, the broadest isotopic niches were observed in juveniles from Máncora, whereas isotopic niches of juveniles from Salaverry and San José were narrower. This difference is primarily driven by the Humboldt Current System and associated upwelling of cold and nutrient rich water that drives increased primary production in San José and, to a less extent, in Salaverry. Compared to smooth hammerhead juveniles from Máncora, those from San José and Salaverry were characterised by higher essential fatty acid concentrations related to pelagic and migratory prey. We conclude that smooth hammerhead juveniles from three nursery areas in northern Peruvian coast differ significantly in their trophic niches. Thus, management and conservation efforts should consider each nursery area as a unique juvenile stock associated with a unique ecosystem and recognize the dependence of smooth hammerhead recruitment in San José and Salaverry on the productivity driven by the Humboldt Current System.

\section{Keywords}

Humboldt Current System, Sharks nursery areas, Denitrification, Feeding dynamics, Isotopic niche 


\section{Introduction}

Many shark species are globally threatened by fisheries due to a significant demand for shark fins in some Asian countries (e.g., China, Korea, Vietnam) (Jacquet et al., 2008; Frisch et al., 2016). Furthermore, due to some life history characteristics such as late sexual maturity, low fecundity and growth rates, high longevity and long gestation periods many shark populations are highly vulnerable (Cortés, 2000). Humboldt Current System (HCS) makes northern Peru fisheries of a variety of species among the most productive on Earth (Kämpf and Chapman, 2016). As a result, Peru ranks among 20 most important shark fin exporters in the world (Dent and Clarke, 2015).

The smooth hammerhead Sphyrna zygaena (Linnaeus, 1758) is a species of international concern, categorised as vulnerable by the International Union for Conservation of Nature (IUCN) and added to Appendix II of the Convention on International Trade in Endangered Species of Wild Fauna and Flora CITES (Rigby et al., 2019). Nevertheless, the smooth hammerhead is among the most appreciated shark species on the Asian market and has become the third most frequently captured shark species in Peru summing up to $15 \%$ of the total shark landings (Clarke et al., 2006; González-Pestana et al., 2016). Furthermore, more than half of these landings correspond to artisanal fishers from the central and northern coast of Peru that operate in three smooth hammerhead nursery areas (González-Pestana et al., 2016).

In the context of nature conservation, a nursery area is a zone where neonates and juveniles of a species are in high abundance and, as such, it is expected to offer some benefits to the juvenile population such as increased food availability or protection from predators (Simpfendorfer and Milward, 1993; Beck et al., 2001; Heupel et al., 2007). Globally, many nursery areas have been described for the smooth hammerhead e.g., in the Atlantic ocean on the coast of Uruguay, on the Brazilian continental shelf and on the coast of South Africa; in the Pacific ocean on the occidental shelf of the North Island at New Zealand (Smale, 1991; Vooren et al., 2005; Doño, 2008; Francis, 2016).

Three nursery areas of smooth hammerhead have been described in the HCS based on the presence and abundance of neonates and juveniles (total length between 53 and $150 \mathrm{~cm}$ ) (González-Pestana, 2014, 2018). One is located in the Tropical East Pacific Marine Province (TEP-MP) at approximately $4^{\circ} \mathrm{S}$ in proximity of Máncora Port and is characterized by high fish diversity (Spalding et al., 2007; IbanezErquiaga et al., 2018). The other two nursery areas are located in the Warm Temperate Southeastern Pacific Marina Province (WTSP-MP), one at approximately $6^{\circ} 40^{\prime} \mathrm{S}$ in proximity of San José Port and one 
at approximately at $8^{\circ} 15^{\prime} \mathrm{S}$ in proximity of Salaverry Port (Spalding et al., 2007). Both of these nursery areas located in WTSP-MP are characterized by high productivity driven by the HCS and high fish biomass and diversity (Chavez et al., 2008; Ibanez-Erquiaga et al., 2018). Furthermore, nursery area at San José Port is characterised by presence of small islands and is limited to continental shelf, whereas nursery area at Salaverry Port does not accommodate islands and spreads further out to oceanic waters.

The ecological niche is commonly defined as a combination of environmental conditions, biotic and abiotic variables, in which the species can persist, use resources, and impact its environment (McGill et al., 2006). The trophic niche is a part of the ecological niche and it describes all trophic interactions of a population or species, its food resources and feeding area (Potapov et al., 2018; Shipley et al., 2018). Since the biochemical composition of an organism is directly related to its feeding habits, it is possible to evaluate an approximation of the trophic niche of a species through analyses of its stable isotopes and fatty acids (Bec et al., 2011). Specifically, the isotopic composition of an organism, its isotopic niche, depends on its diet, feeding habits and trophic interactions (Newsome et al., 2007). Fatty acid composition can also be used as a trophic marker because it directly relates to the lipid reserve obtained by feeding (Dalsgaard et al., 2003). Even though, the majority of fatty acids can be synthetized by an organism, still most of them are obtained directly from consumed food (Iverson et al., 2004). As such, a combination of stable isotope analyses and evaluation of fatty acid profiles can be a powerful tool to obtain comprehensive, time integrated (weeks to a year) assessment of diet and feeding behaviour and, therefore, approximate the trophic niche of a marine predator (Hooker et al., 2001).

Nursery areas are expected to bring benefits to juvenile populations and are essential for adult population recruitment (Heupel et al., 2007). Increasing fishery pressure on nurseries of the smooth hammerhead in northern Peruvian waters can be a serious threat to sustainability of this fishery. However, ecosystem-based fisheries management has not been implemented in Peruvian waters due to lack of data on biology and ecology of commercially important elasmobranch species. This study aims to evaluate the trophic niche of juvenile smooth hammerheads from three nursery areas using stable isotope and fatty acid analysis in northern Peruvian waters to inform conservation. As each of the nursery area is under influence of different water masses and is characterised by different environmental conditions, we expect trophic niches of smooth hammerhead juveniles to be significantly different among nursery areas. 
116

117

118

119

120

121

122

123

124

125

126

127

128

129

130

131

132

133

134

135

136

137

138

139

140

141

142

143

144

145

\section{Methodology}

- Study area

Data on presence of juvenile smooth hammerheads recorded by artisanal fishers and monitors of ProDelphinus, an NGO dedicated to fishery conservation, between June 2014 and December 2018 were used to delimitate specific nursery areas in northern Humboldt Current System (HCS) (Fig. 1). Sea surface temperature (SST) and chlorophyll $a(\mathrm{Chl}-a)$ data series were obtained from NASA MODIS-Aqua (Moderate Resolution Imaging Spectrometer Aqua) via Oceancolor Data Downloader (https://oceandata.sci.gsfc.nasa.gov/MODIS-Aqua/). Satellite images with $4 \mathrm{~km}^{2}$ spatial resolution were downloaded at seasonal scale between 2010 and 2019. Specific seasons were divided as follows: Summer (December - February), Autumn (March - May), Winter (June - August) and Spring (September - November). In addition, information on occurrence of ENSO oscillation events was obtained from NOAA Climate Prediction Center (https://www.cpc.ncep.noaa.gov/).

- Sample collection

Juvenile smooth hammerheads that were captured as bycatch by artisanal gillnet fishers between February and March 2019 in each nursery area were used with the approval of Peruvian Ministerio de la Producción (PRODUCE), registry N00008103-2019. Muscle and liver tissue samples were extracted from each individual and its total length (TL) was registered. Due to time limitations some fishers provided sample of only one of the tissues. Since smooth hammerheads are born with a large liver that carries nutrients from maternal heritage that are expected to affect isotopic signature and fatty acid profiles of neonates (Francis, 1994; Olin et al., 2011), only juveniles between 70 and $120 \mathrm{~cm}$ TL were considered for this study. Furthermore, muscle tissue of sympatric fish and squid species that are usually caught together with smooth hammerhead were also collected by artisanal fishers in the same period (the number of available samples depended on both availability of fish and squid and time that could be dedicated by the fishers for sample collection). Tissues samples of smooth hammerheads and sympatric species were preserved in $80 \%$ ethanol (since collection areas were remote and no others preservation options were accessible), and upon arrival to the laboratory were lyophilized for further analyses.

Ethanol preservation may either deplete or enrich isotopic signatures of carbon and nitrogen, however there is no consensus whether a correction factor should be applied or not (Sarakinos et al., 2002; Xu et al., 2011). Furthermore, direct evaluations of the effects of ethanol fixation on fatty acid profiles are scarce, but Phleger et al. (2001) found no differences in fatty acid profile of ethanol-preserved samples 
146 of rock lobster in comparison with frozen or lyophilized samples. Furthermore, all samples in our study

147 were preserved with the same method allowing for valid comparisons among the nursery areas. The 148 total of smooth hammerhead muscle samples obtained was 10 in Máncora (115.2 $\pm 5.7 \mathrm{~cm}$ TL), 19 in San 149 José $(80.2 \pm 6.3 \mathrm{~cm} \mathrm{TL})$ and 14 in Salaverry $(81.1 \pm 2.5 \mathrm{~cm} \mathrm{TL})$. The total smooth hammerhead liver 150 samples obtained was 13 in Máncora (114.4 $\pm 5.2 \mathrm{~cm} \mathrm{TL}), 17$ in San José (80.3 $\pm 6.6 \mathrm{~cm} \mathrm{TL})$ and 14 in 151 Salaverry $(81.1 \pm 2.5 \mathrm{~cm} \mathrm{TL})$.

$152 \quad-\quad$ Stable isotope analysis

153 Lipid content of tissue subsamples that were used for stable isotope analyses was extracted to prevent 154 the alteration of carbon stable isotope signatures (Sweeting et al., 2006). Lipid extraction was performed following the methods described by Folch et al. (1957) modified by Cequier-Sánchez et al. (2008) and Urzúa and Anger (2013). We used $20 \mathrm{mg}$ of tissue and $5 \mathrm{ml}$ of the solvent dichloromethane: methanol (2:1). Subsequently, all muscle samples were dried, pulverized and $1 \mathrm{mg}$ of each sample was placed inside a tin capsule for analyses of the composition of carbon and nitrogen stable isotopes. Samples were sent to stable isotopes laboratory at University of California in Davis, USA (https://stableisotopefacility.ucdavis.edu). To assess the variation in isotopic ratios of carbon and nitrogen $\delta$ notations were calculated following the equation (Coplen, 2011):

$$
\delta^{h} \mathrm{X}=\left(\frac{R_{\text {sample }}}{R_{\text {standard }}}-1\right)
$$

Where $\mathrm{X}$ is the element, $h$ is the high mass number, $\mathrm{R}_{\text {sample }}$ is the high mass-to-low mass isotope ratio of the sample and $R_{\text {standard }}$ is the high mass-to-low mass isotope ratio of the standard (Vienna Pee Dee Belemnite for carbon and atmospheric nitrogen for nitrogen). The $\delta$ ratio was expressed in parts per thousand (\%o).

When working with stable isotope in elasmobranch tissue, it is recommended to extract lipid and urea (Ingram et al., 2007; Li et al., 2016; Carlisle et al., 2017). In this study, as urea extractions were not performed, we used the correction factor from Li et al. (2016) for smooth hammerhead to correct the $\delta^{15} \mathrm{~N}$ values following the equation:

$$
\delta^{15} N_{L E+U E}=0.984 * \delta^{15} N_{L E}+2.063
$$

172 Where $\delta^{15} \mathrm{~N}_{\mathrm{LE}+\mathrm{UE}}$ is the value of $\delta^{15} \mathrm{~N}$ corrected with lipid extraction (LE) and urea extraction (UE). 
174 The fatty acid profile was determined following the methods presented by Urzúa and Anger (2011).

175 Fatty acid methyl esters (FAMEs) were measured after preparation using the total lipid extracted from

176 each sample (Couturier et al., 2020). Total lipid extracts were esterified using methanolic sulphur acid at

$17770^{\circ} \mathrm{C}$ for $1 \mathrm{~h}$ in a Thermo-Shaker (MRC model DBS-001). Subsequently, fatty acids were rinsed using $6 \mathrm{ml}$

178 of $\mathrm{n}$-hexane. Finally, the measurement of FAMEs was performed using a gas chromatograph (Agilent,

179 model 7890A) equipped with a DB-225 column (J \& W Scientific, $30 \mathrm{~m}$ in length, $0.25 \mathrm{~mm}$ inner diameter

180 and $0.25 \mu \mathrm{m}$ film thickness) at a range of temperatures. Individual FAMEs were identified by comparison

181 to known fatty acid standards of marine origin using chromatograph software (Agilent ChemStation,

182 USA) and certificate material Supelco 37 FAME mix 47885-U, and quantified by means of the response

183 factor to internal standard 23:0 FA added prior to transmethylation (Malzahn et al., 2007; Urzúa and

184 Anger, 2011).

$185 \quad-\quad$ Statistical analyses

186 To compare the environmental variables among three nursery areas we used repeated measures

187 ANOVA (ANOVA-RM) and post-hoc test with Bonferroni correction. The factors used in the model were:

188 nursery areas as groups, years as intra-case factor and seasons as cases. PERMANOVA was used to

189 compare stable isotope signatures $\left(\delta^{13} \mathrm{C}\right.$ and $\left.\delta^{15} \mathrm{~N}\right)$ among nursery areas (Máncora, San José, Salaverry)

190 and tissue types (muscle, liver) (Anderson, 2001; Mcardle et al., 2001). Subsequently, niche sizes and

191 niche overlaps of the smooth hammerheads were compared among the nursery areas using nicheROVER

192 package in R (Lysy et al., 2014; Swanson et al., 2015). This package evaluates the niche size $\left(\mathrm{N}_{\mathrm{s}}\right)$ as the

$19395 \%$ of the region occupied by the species or population. Niche overlap is calculated by a Bayesian

194 framework with $95 \%$ of the area of the ellipses based on data points. Subsequently, the overlap is

195 calculated as the probability of the individual from one area to share the isotopic space with an

196 individual from another area. An overlap higher than $60 \%$ is consider significant by criteria used in niche

197 studies (Schoener, 1968). In addition, the package "tRophicPosition" was used to compare trophic

198 position $\left(T_{P}\right)$ of juvenile smooth hammerheads among nursery areas. This package calculates Bayesian $T_{P}$

199 estimates using $\delta^{15} \mathrm{~N}$ from the base line (sympatric species) (Quezada-Romegialli et al., 2018). We used

200 discrimination factors specific for smooth hammerhead that were estimated by Kim et al. (2012): $1.7 \pm$

2010.5 for $\delta^{13} \mathrm{C}$ and $3.7 \pm 0.4$ for $\delta^{15} \mathrm{~N}$. Sympatric species were assumed to represent $T_{p}$ of 3.6, which is the

202 mean value of the trophic position of secondary fish consumers in the HCS (Espinoza et al., 2017).

203 Comparisons of isotopic signatures between smooth hammerhead juveniles and sympatric species were

based on liver signatures of smooth hammerheads because liver has a higher isotopic turnover rate

Peer) reviewing PDF | (2020:11:55838:1:1:NEW 1 Mar 2021) 
205 compared to muscle and therefore it is expected to reflect more recent diet and be less affected by

206 maternal signature.

207 To compare fatty acid diversity among nursery areas, ANOVA was performed on the Shannon diversity 208 index $\left(H^{\prime}\right)$ calculated for fatty acid profiles in each tissue and nursery area (Shannon, 1948). Data were 209 log transformed prior to analyses to meet ANOVA assumptions. Subsequently, PERMANOVA based on

210 Bray-Curtis dissimilarity matrix was used to compare fatty acid profiles and isotopic signatures $\left(\delta^{13} \mathrm{C}\right.$ and

$211 \delta^{15} \mathrm{~N}$ ) together among nursery areas (estimated probabilities were based on 999 permutations).

212 Absolute values of $\delta^{13} \mathrm{C}$ were used and all data were square root transformed prior to analyses to reduce

213 the effects of outliers. Subsequently, to assess which response variables were the most important

214 drivers of differences among nursery areas we used Principal Coordinate Ordination (PCO) (Anderson,

215 2017). Variables with Pearson correlation higher than 0.5 were plotted (Meyer et al., 2019). All

216 multivariate statistical analyses were executed in PRIMER 6 (Plymouth Routines In Multivariate

217 Ecological Research) (Clarke and Warwick, 2001). 


\section{Results}

$219-\quad$ Environmental factors

220 We found significant differences in SST (ANOVA-RM of Area * Years: $F_{(16,3)}=2.26 ; p=0.02$ ) and chlorophyll $a$ (ANOVA-RM of Area * Years: $\mathrm{F}_{(16,3)}=4.78 ; \mathrm{p}<0.001$ ) among the nursery areas. Specifically, Máncora was characterized by SST consistently $2^{\circ} \mathrm{C}$ higher compared to Salaverry. Furthermore, SST in Salaverry was consistently $1^{\circ} \mathrm{C}$ higher compared to San José (Supplementary Fig. 1). In contrast, chlorophyll a concentration in San José were consistently about $2 \mathrm{mg} \mathrm{m}^{-3}$ higher compared to Máncora and Salaverry (Supplementary Fig. 2).

Smooth hammerhead juveniles captured in Salaverry had similar isotopic signatures compared to those captured in Máncora but were slightly enriched in ${ }^{15} \mathrm{~N}$ (higher $\delta^{15} \mathrm{~N}$ values; Fig. 2). Furthermore, the highest variability of isotopic signatures in both tissues was observed in smooth hammerhead juveniles captured in Máncora. Smooth hammerhead juveniles captured in San José were characterised by isotopic signatures enriched in ${ }^{13} \mathrm{C}$ and ${ }^{15} \mathrm{~N}$ in both liver and muscle tissues $\left(\delta^{13} \mathrm{C}\right.$ and $\delta^{15} \mathrm{~N}$ values significantly higher) compared to those captured in Salaverry and Máncora and these differences were more marked in liver tissue (Fig. 2; PERMANOVA; $F=39 ; p=0.001$ ). Elliptical isotopic niche projections showed significant overlap between the three nursery areas (> 60 \%; Fig. 3; Table 1). The broadest isotopic niches were observed in smooth hammerhead juveniles from Máncora, whereas isotopic niches of smooth hammerhead juveniles from Salaverry and San José were narrower. These differences were consistent between results based on muscle and liver tissues. Sympatric species captured in all nursery areas were characterized by carbon signatures consistently enriched in ${ }^{13} \mathrm{C}$ compared to carbon signatures of smooth hammerhead juveniles from the same areas (Fig. 4). in both muscle and liver tissues. Furthermore, only saturated fatty acids were recorded in muscle, while in the liver tissue saturated fatty acids were found in the highest concentrations (Table 2). Juvenile smooth hammerhead from Salaverry and San José were also characterised by the highest concentrations of saturated fatty acids, but polyunsaturated fatty acids were also found in these individuals in both muscle and liver tissues. The highest diversity $\left(\mathrm{H}^{\prime}\right)$ of fatty acids in muscle tissue was

247 found in smooth hammerhead juveniles from Salaverry (1.02 \pm 0.6$)$ followed by San José $(1 \pm 0.4)$, 
248 whereas diversity of fatty acids was significantly lower in smooth hammerhead juveniles from Máncora

$249(0.46 \pm 0.3)(F=6.42 ; P=0.004)$. Similar pattern was observed in diversity of fatty acids in liver tissue.

250 Specifically, $\mathrm{H}^{\prime}$ of fatty acids of smooth hammerhead juveniles from Salaverry $(1.93 \pm 0.2)$ and San José

251 (1.92 \pm 0.1$)$ were significantly higher compared to smooth hammerhead juveniles from Máncora (0.76 \pm

$2520.2)(\mathrm{F}=6.42 ; P=0.004)$.

253 - Differences in trophic niche based on isotopic signatures and fatty acid profiles among the $254 \quad$ nursery areas

255

256

257

258

259

260

261

262

263

264

265
PERMANOVAs based on fatty acid concentrations together with isotopic signatures $\left(\delta^{13} \mathrm{C}\right.$ and $\left.\delta^{15} \mathrm{~N}\right)$ indicated significant differences between smooth hammerhead juveniles from Máncora and smooth hammerhead juveniles from San José and Salaverry in muscle $(F=4.83 ; P=0.004)$ and liver $(F=3.54 ; P=$ 0.002). Furthermore, PCO based on fatty acid concentrations together with isotopic signatures in muscle tissue clearly separates smooth hammerhead juveniles captured in San José and Salaverry from those captured in Máncora mainly due to higher overall fatty acid concentrations of those captured in San José and Salaverry (Fig. 5A). Similar pattern was observed in PCO based on both fatty acid concentrations and isotopic signatures in liver tissue but here, in addition to higher fatty acid concentration, smooth hammerhead juveniles from Salaverry and San José were also characterized by carbon enriched in heavier ${ }^{13} \mathrm{C}$ isotope (Fig. 5B). 
266

\section{Discussion}

267 Significant differences in trophic niches based on stable isotope signatures and fatty acid profiles among three nursery areas suggest distinct trophic dynamics of juvenile smooth hammerheads in each area largely driven by the HCS. Furthermore, isotopic signatures corroborate that juvenile smooth hammerheads from San José nursery area feed on prey enriched in heavier isotopes of carbon and nitrogen, compared to juvenile smooth hammerheads from Salaverry and Máncora nursery areas. In addition, smooth hammerheads from the San José and Salaverry nursery areas were characterised by similar fatty acid profiles that were significantly more diverse compared to the fatty acid profile of smooth hammerheads from Máncora.

The influence of the HCS and related coastal upwelling amplified by the extensive continental shelf results in low water temperatures and high nutrient concentrations in the nursery areas of San José and Salaverry (Chavez et al., 2008; Morales et al., 2019). The differences we observed in temperature and chlorophyll- $a$ among the areas are maintained over time despite the seasonal variability related to $\mathrm{EI}$ Niño Southern Oscillation (ENSO) cycles (Fiedler, 2002). Carbon signatures are also directly affected by the influence of HCS that result in enrichment in the heavier ${ }^{13} \mathrm{C}$ isotope between 7 and $15^{\circ} \mathrm{S}$ (Echevin et al., 2008; Argüelles et al., 2012). Furthermore, the presence of an Oxygen Minimum Zone (OMZ) in the northern HCS intensifies denitrification and enrichment of ${ }^{15} \mathrm{~N}$ isotope available for photosynthesis (Liu and Kaplan, 1989; Chavez et al., 2008; Paulmier and Ruiz-Pino, 2009). This influence of the HCS can explain enrichment of juvenile smooth hammerheads captured in the San José nursery area in ${ }^{13} \mathrm{C}$ and

${ }^{15} \mathrm{~N}$ isotopes. Similar enrichment could be expected for juvenile smooth hammerhead captured in Salaverry nursery area. However, juvenile smooth hammerheads from Salaverry were characterised by isotopic signatures and isotopic niche width similar to those captured in Máncora with lower concentrations of heavier ${ }^{13} \mathrm{C}$ and ${ }^{15} \mathrm{~N}$ isotopes. This is probably because juvenile smooth hammerheads from Salaverry feed in more oceanic waters, where carbon and nitrogen isotopic signatures are characterized by lower concentrations of ${ }^{13} \mathrm{C}$ and ${ }^{15} \mathrm{~N}$ isotopes, similar to those observed in Máncora nursery area (Echevin et al., 2008; Argüelles et al., 2012; Rabehagasoa et al., 2012). The probability that juvenile smooth hammerheads captured in Salaverry and Máncora migrate between these two nursery areas is low since smooth hammerheads are characterized by high fidelity to nursery areas where they were born (Holland et al., 1993). 
296 Sympatric species, mostly fishes, that were evaluated within this study showed isotopic signatures

297 enriched in ${ }^{13} \mathrm{C}$ isotope compared to isotopic signature in the livers of juvenile smooth hammerheads.

298 Therefore, species that were available for this study most probably are not consumed by juvenile 299 smooth hammerheads. Indeed, squids, species from oceanic water, were previously documented to be 300 the most important prey of juvenile hammerheads based on stomach content analyses (Bornatowski et 301 al., 2007; Galván-magaña et al., 2013; González-Pestana et al., 2017; Dicken et al., 2018). Few jumbo squid Dosidicus gigas samples that were analyzed within this study were characterized by lower concentrations of ${ }^{15} \mathrm{~N}$ isotope compared to smooth hammerhead juveniles. This suggests jumbo squid as potential prey of smooth hammerhead, however analyses of larger amount of samples is needed to corroborate this finding. Other recent studies based on stable isotope analyses suggest that also demersal fishes and crabs may significantly contribute to the diet of juvenile smooth hammerheads (Kiszka et al., 2015; Loor-andrade et al., 2015; Rosende-Pereiro et al., 2020). Exhaustive sampling of sympatric species and development of isotopic baselines in all nursery areas including at least two seasons is recommended to elucidate the specific prey contributing to the diet of juvenile smooth hammerheads.

Fatty acid biomarkers complement analyses of stable isotopes and allow to elucidate further differences in trophic niches among nursery areas. The presence of polyunsaturated and saturated fatty acids (PUFA and SFA) in muscle and liver are indicators of pelagic zooplanktivorous prey such as squids and fishes (Pethybridge et al., 2010; Rohner et al., 2013). Juvenile smooth hammerheads from San José and Salaverry were characterized by higher concentrations of these fatty acids, probably due to a higher biomass of pelagic prey in these nursery areas driven by the HCS. The meristic acid (C14:0) detected in muscle and liver tissues of smooth hammerhead juveniles from San José and Salaverry nursery areas may indicate higher abundances of proteobacteria and diatoms in these areas most probably as a result of the HCS and coastal upwelling (Dalsgaard et al., 2003). Polyunsaturated EPA (C20:5n3) and DHA (C22:6n3) are the most relevant as dietary indicators as they cannot be synthetized by sharks (Turner and Rooker, 2005). These fatty acids are positively correlated to total length as they are usually depleted in sharks under one year (Wai et al., 2011, 2012; Belicka et al., 2012). Our results do not corroborate this relationship for smooth hammerhead juveniles as the largest individuals were captured in Máncora and were characterised by the lowest concentrations of EPA and DHA. In contrast, smooth hammerhead juveniles from San José and Salaverry nursery areas were characterised by higher concentration of both 
327 EPA and DHA perhaps due to lower temperatures and higher abundances of prey such as squids or

328 migratory fishes driven by the influence of the HCS (Bell et al., 1986; Saito et al., 1997; Semeniuk et al.,

329 2007; Beckmann et al., 2013).

330 In comparison with previous studies, we found lower diversity of fatty acids in muscle tissue of smooth

331 hammerheads (Davidson et al., 2011, 2014). This difference could be related to the differences in

332 extraction protocol as studies by Davidson et al. used $20 \mathrm{mg}$ of lipids, while due to limited sample

333 availability we used the lipids extracted from $20 \mathrm{mg}$ of tissue. We still found the results of muscle tissue

334 analyses worth presenting as the fatty acid profiles that we found in liver tissues were similar to profiles

335 found in muscle tissue found in the same individuals and, as expected, the concentrations in liver tissue 336 were higher.

337 - Smooth hammerhead trophic niche and its implications for fishery management and 338 conservation

339 Integration of the stable isotope signatures and fatty acid profiles allowed differentiation of Smooth 340 Hammerhead juveniles among San José, Salaverry and Máncora nursery areas. The trophic niche of a 341 species or population consists of biotic and abiotic variables related to feeding habits and here we 342 document that smooth hammerhead juveniles from each nursery area in Peruvian waters have distinct trophic niches characterised by specific types and quantities of prey they consume and their feeding habitats (oceanic or coastal waters).

The smooth hammerhead is among the elasmobranchs species most frequently landed in the Peru and its catches severely declined during recent years (González-Pestana et al., 2016). Conservation initiatives and implementation of ecosystem based fishery management are urgently needed to sustain this fishery, however they lack essential baseline data (Lack et al., 2014). We document that smooth hammerhead juveniles from three nursery areas in northern Peru differ significantly in their diets and trophic niches. Thus, management and conservation efforts should consider each nursery area as a unique juvenile stock associated with unique ecosystem and recognize the dependence of Smooth Hammerhead recruitment in San José and Salaverry on the productivity driven by the Humboldt Current System. Additional research could be undertaken to further refine our understanding of the spatial, temporal and environmental characteristics of these nursery areas and their stability over time given potential ENSO impacts. Our results and future studies may inform ecosystem-based fishery 
357 358

Simpfendorfer, 2009; Mason et al., 2020). New measures could build upon existing seasonal bans and landings restriction to take into account protection of distinct nursery areas. To be most effective, any future monitoring or management actions should involve fishers and communities that operate in these nursery areas to help design management measures that allow for both sustainable shark populations and sustainable fisheries. Ecosystem-based co-management may be instrumental in enhancing rapidly declining smooth hammerhead populations.

\section{Acknowledgment}

This study was performed with the support of Small Grant SOSF 521 from the Save Our Seas Foundation. Artisanal fishers from Máncora, San José and Salaverry ports are greatly acknowledged for their help in sample collection. Colleagues from Ko_Lab and Laboratorio de Recursos Hidrobiológicos are acknowledged for help in sample processing.

\section{References}

Anderson, M.J. 2001. A new method for non-parametric multivariate analysis of variance. Austral Ecol. 26:32-46. https://doi.org/10.1080/13645700903062353.

Anderson, M.J. 2017. Permutational Multivariate Analysis of Variance (PERMANOVA). Wiley StatsRef Stat. Ref. Online 1-15. https://doi.org/10.1002/9781118445112.stat07841.

Argüelles, J., Lorrain, A., Cherel, Y., Graco, M., Tafur, R., Alegre, A., Espinoza, P., Taipe, A., Ayón, P., and Bertrand, A. 2012. Tracking habitat and resource use for the jumbo squid Dosidicus gigas: A stable isotope analysis in the Northern Humboldt Current System. Mar. Biol. 159:2105-2116. https://doi.org/10.1007/s00227-012-1998-2.

Bec, A., Perga, M.E., Koussoroplis, A., Bardoux, G., Desvilettes, C., Bourdier, G., and Mariotti, A. 2011. Assessing the reliability of fatty acid-specific stable isotope analysis for trophic studies. Methods Ecol. Evol. 2:651-659. https://doi.org/10.1111/j.2041210X.2011.00111.x.

Beck, M.W., Heck, K.L., Able, K.W., Childers, D.L., Eggleston, D.B., Gillanders, B.M., Halpern, B., Hays, C.G., Hoshino, K., Minello, T.J., Orth, R.J., Sheridan, P.F., and Weinstein, M.P. 2001. The identification, conservation, and management of estuarine and marine nurseries for fish and invertebrates. Bioscience 51:633-641.

Beckmann, C.L., Mitchell, J.G., Stone, D.A.J., and Huveneers, C. 2013. A controlled feeding experiment investigating the effects of a dietary switch on muscle and liver fatty acid profiles in Port Jackson sharks Heterodontus portusjacksoni. J. Exp. Mar. Bio. Ecol. 448:10-18. https://doi.org/10.1016/j.jembe.2013.06.009. 
395

396

397

398

399

400

401

402

403

404

405

406

407

408

409

410

411

412

413

414

415

416

417

418

419

420

421

422

423

424

425

426

427

428

429

430

431

432

433

434

435

436
Belicka, L.L., Matich, P., Jaffé, R., and Heithaus, M.R. 2012. Fatty acids and stable isotopes as indicators of early-life feeding and potential maternal resource dependency in the bull shark Carcharhinus leucas. Mar. Ecol. Prog. Ser. 455:245-256. https://doi.org/10.3354/meps09674.

Bell, M. V, Henderson, R.J., and Sargent, J.R. 1986. The role of polyunsaturated fatty acids in fish. Comp. Biochem. Physiol. Part B Comp. Biochem. 83:711-719. https://doi.org/10.1016/0305-0491(86)90135-5.

Bornatowski, H., Costa, L., Robert, M. de C., and Pina, J.V. da 2007. Hábitos alimentares de tubarões-martelo jovens, Sphyrna zygaena (Carcharhiniformes: Sphyrnidae), no litoral sul do Brasil. Biota Neotrop. 7:213-216. https://doi.org/10.1590/s167606032007000100025.

Carlisle, A.B., Litvin, S.Y., Madigan, D.J., Lyons, K., Bigman, J.S., Ibarra, M., and Bizzarro, J.J. 2017. Interactive effects of urea and lipid content confound stable isotope analysis in elasmobranch fishes. Can. J. Fish. Aquat. Sci. 74:419-428. https://doi.org/10.1139/cjfas-2015-0584.

Cequier-Sánchez, E., Rodríguez, C., Ravelo, Á.G., and Zárate, R. 2008. Dichloromethane as a solvent for lipid extraction and assessment of lipid classes and fatty acids from samples of different natures. J. Agric. Food Chem. 56:4297-4303.

Chavez, F.P., Bertrand, A., Guevara-Carrasco, R., Soler, P., and Csirke, J. 2008. The northern Humboldt Current System: Brief history, present status and a view towards the future. Prog. Oceanogr. 79:95-105. https://doi.org/10.1016/j.pocean.2008.10.012.

Clarke, K.R., and Warwick, R.M. 2001. A further biodiversity index applicable to species lists: Variation in taxonomic distinctness. Mar. Ecol. Prog. Ser. 216:265-278. https://doi.org/10.3354/meps216265.

Clarke, S.C., McAllister, M.K., Milner-Gulland, E.J., Kirkwood, G.P., Michielsens, C.G.J., Agnew, D.J., Pikitch, E.K., Nakano, H., and Shivji, M.S. 2006. Global estimates of shark catches using trade records from commercial markets. Ecol. Lett. 9:1115-1126. https://doi.org/10.1111/j.1461-0248.2006.00968.x.

Coplen, T.B. 2011. Guidelines and recommended terms for expression of stable-isotoperatio and gas-ratio measurement results. Rapid Commun. Mass Spectrom. 25:2538-2560. https://doi.org/10.1002/rcm.5129.

Cortés, E. 2000. Life History Patterns and Correlations in Sharks. Rev. Fish. Sci. 8:299_- 
438

439

440

441

442

443

444

445

446

447

448

449

450

451

452

453

454

455

456

457

458

459

460

461

462

463

464

465

466

467

468

469

470

471

472

473

474

475

476

477

478
Couturier, L.I.E., Michel, L.N., Amaro, T., Budge, S.M., da Costa, E., De Troch, M., Di Dato, V., Fink, P., Giraldo, C., Le Grand, F., Loaiza, I., Mathieu-Resuge, M., Nichols, P.D., Parrish, C.C., Sardenne, F., Vagner, M., Pernet, F., and Soudant, P. 2020. State of art and best practices for fatty acid analysis in aquatic sciences. ICES J. Mar. Sci.

https://doi.org/10.1093/icesjms/fsaa121.

Dalsgaard, J., John, M.S., Kattner, G., Müller-Navarra, D., and Hagen, W. 2003. Fatty acid trophic markers in pelagic marine environment. Adv. Mar. Biol. 46:225-340.

https://doi.org/https://doi.org/10.1016/S0065-2881(03)46005-7.

Davidson, B.C., Nel, W., Rais, A., Namdarizandi, V., Vizarra, S., and Cliff, G. 2014. Comparison of total lipids and fatty acids from liver, heart and abdominal muscle of scalloped (Sphyrna lewini) and smooth (Sphyrna zygaena) hammerhead sharks.

Springerplus 3:521. https://doi.org/10.1186/2193-1801-3-521.

Davidson, B.C., Sidell, J., Rhodes, J., and Cliff, G. 2011. A comparison of the heart and muscle total lipid and fatty acid profiles of nine large shark species from the east coast of South Africa. Fish Physiol. Biochem. 37:105-112. https://doi.org/10.1007/s10695-0109421-8.

Dent, F., and Clarke, S.C. 2015. State of the global market for shark products. FAO Fisheries and Aquaculture Technical Paper No. 590. Rome, FAO. 187 pp.

Dicken, M.L., Winker, H., Smale, M.J., and Cliff, G. 2018. Sharks caught in the KwaZuluNatal bather protection programme, South Africa. 14. The smooth hammerhead shark Sphyrna zygaena (Linnaeus). African J. Mar. Sci. 40:157-174. https://doi.org/10.2989/1814232X.2016.1198276.

Doño, F.M. 2008. Identificación y caracterización de áreas de cría del tiburón martillo (Sphyrna spp) en las Costas de Uruguay. Universidad de la Republica. Facultad de Ciencias. $34 \mathrm{pp}$.

Echevin, V., Aumont, O., Ledesma, J., and Flores, G. 2008. The seasonal cycle of surface chlorophyll in the Peruvian upwelling system: A modelling study. Prog. Oceanogr. 79:167176. https://doi.org/10.1016/j.pocean.2008.10.026.

Espinoza, P., Lorrain, A., Ménard, F., Cherel, Y., Tremblay-Boyer, L., Argüelles, J., Tafur, R., Bertrand, S., Tremblay, Y., Ayón, P., Munaron, J.-M., Richard, P., and Bertrand, A. 2017. Trophic structure in the northern Humboldt Current system: new perspectives from stable isotope analysis. Mar. Biol. 164:86. https://doi.org/10.1007/s00227-017-3119-8. 
479

480

481

482

483

484

485

486

487

488

489

490

491

492

493

494

495

496

497

498

499

500

501

502

503

504

505

506

507

508

509

510

511

512

513

514

515

516

517

518

519
Fiedler, P.C. 2002. Environmental change in the eastern tropical Pacific Ocean: Review of ENSO and decadal variability. Mar. Ecol. Prog. Ser. 244:265-283.

https://doi.org/10.3354/meps244265.

Folch, J., Lees, M., and Sloane, S.G.H. 1957. A simple Method for the Isolation and purification of total lipides from animal tissues. J. Biol. Chem. 226:497-509.

Francis, M.P. 1994. Reproduction, embryonic development, and growth of the porbeagle shark, Lamna nasus, in the southwest Pacific Ocean. Fish. Bull. 98:41-63.

Francis, M.P. 2016. Distribution, habitat and movement of juvenile smooth hammerhead sharks (Sphyrna zygaena) in northern New Zealand. New Zeal. J. Mar. Freshw. Res. p. 506-525., Vol. 50. https://doi.org/10.1080/00288330.2016.1171244.

Frisch, A.J., Ireland, M., Rizzari, J.R., Lönnstedt, O.M., Magnenat, K.A., Mirbach, C.E., and Hobbs, J.-P.A. 2016. Reassessing the trophic role of reef sharks as apex predators on coral reefs. Coral Reefs 35:459-472. https://doi.org/10.1007/s00338-016-1415-2.

Galván-magaña, F., Polo-silva, C., Hernández-aguilar, S.B., Sandoval-Londoño, A., Ochoadíaz, M.R., Aguilar-castro, N., Castañeda-Suárez, D., Chavez-Costa, A., BaigorríSantacruz, Á., Torres-Rojas, Y., and Abitia-Cárdenas, L.A. 2013. Shark predation on cephalopods in the Mexican and Ecuadorian Pacific Ocean. Deep. Res. II 95:52-62. https://doi.org/10.1016/j.dsr2.2013.04.002.

González-Pestana, A. 2018. Habitat Suitability of Juvenile Smooth Hammerhead Shark (Sphyrna zyagena) off northern Peru. James Cook University. Marine Sciencies. 47 pp.

González-Pestana, A. 2014. Ecología trófica y áreas de crianza del tiburón martillo, Shyrna zygaena (Linnaeus 1758), juvenil en la zona norte del Perú. Universidad Científica del Sur. Biología Marina y Econegocios. 110 pp.

González-Pestana, A., Acuña-Perales, N., Coasaca-Cespedes, J., Cordova-Zavaleta, F., Alfaro-Shigueto, J., Mangel, J.C., and Espinoza, P. 2017. Trophic ecology of the smooth hammerhead shark (Sphyrna Zygaena) off the coast of northern Peru. Fish. Bull. 115:451459. https://doi.org/10.7755/FB.115.4.2.

González-Pestana, A., Kouri, C.J., and Velez-zuazo, X. 2016. Shark fisheries in the Southeast Pacific : A 61-year analysis from Peru [ version 2; peer review : 1 approved, 2 approved with reservations ]. F1000Research 3:164.

https://doi.org/10.12688/F1000RESEARCH.4412.2. 
520

521

522

523

524

525

526

527

528

529

530

531

532

533

534

535

536

537

538

539

540

541

542

543

544

545

546

547

548

549

550

551

552

553

554

555

556

557

558

559

560
Heupel, M.R., Carlson, J.K., and Simpfendorfer, C.A. 2007. Shark nursery areas: Concepts, definition, characterization and assumptions. Mar. Ecol. Prog. Ser. 337:287-297. https://doi.org/10.3354/meps337287.

Holland, K.N., Wetherbee, B.M., Peterson, J.D., and Lowe, C.G. 1993. Movements and distribution of hammerhead shark pups S. lewini. Copeia 2:495-502.

Hooker, S.K., Iverson, S.J., Ostrom, P.H., and Smith, S.C. 2001. Diet of northern bottlenose whales inferred from fatty-acid and stable-isotope analyses of biopsy samples. Can. J. Fish. Aquat. Sci. 79:1442-1454. https://doi.org/10.1139/cjz-79-8-1442.

Ibanez-Erquiaga, B., Pacheco, A.S., Rivadeneira, M.M., and Tejada, C.L. 2018. Biogeographical zonation of rocky intertidal communities along the coast of Peru (3.5-13.5 S Southeast Pacific). PLoS One 13:1-19. https://doi.org/10.1371/journal.pone.0208244.

Ingram, T., Matthews, B., Harrod, C., Stephens, T., Grey, J., Markel, R., and Mazumder, A. 2007. Lipid extraction has little effect on the $\delta 15 \mathrm{~N}$ of aquatic consumers. Limnol.

Oceanogr. Methods 5:338-342. https://doi.org/10.4319/lom.2007.5.338.

Iverson, S.J., Field, C., Bowen, W.D., and Blanchard, W. 2004. Quantitative fatty acid signature analysis: A new method of estimating predator diets. Ecol. Monogr. 74:211-235. https://doi.org/10.1890/02-4105.

Jacquet, J., Alava, J.J., Pramod, G., Henderson, S., and Zeller, D. 2008. In hot soup: sharks captured in Ecuador's waters. Environ. Sci. 5:269-283.

https://doi.org/10.1080/15693430802466325.

Kämpf, J., and Chapman, P. 2016. Upwelling Systems of the World. A scientific journey to the most productive marine ecosystems. Springer Nature, Switzerland., 1st ed. https://doi.org/10.1007/978-3-319-42524-5.

Kim, S.L., del Rio, C.M., Casper, D., and Koch, P.L. 2012. Isotopic incorporation rates for shark tissues from a long-term captive feeding study. J. Exp. Biol. 215:2495-2500. https://doi.org/10.1242/jeb.070656.

Kinney, M.J., and Simpfendorfer, C.A. 2009. Reassessing the value of nursery areas to shark conservation and management. Conserv. Lett. 2:53-60. https://doi.org/10.1111/j.1755-263x.2008.00046.x.

Kiszka, J.J., Aubail, A., Hussey, N.E., Heithaus, M.R., Caurant, F., and Bustamante, P. 
561
2015. Plasticity of trophic interactions among sharks from the oceanic south-western Indian Ocean revealed by stable isotope and mercury analyses. Deep. Res. Part I 96:49-58.

https://doi.org/10.1016/j.dsr.2014.11.006.

Lack, M., Sant, G., Burgener, M., and Okes, N. 2014. Development of a Rapid Management-Risk Assessment Method for Fish Species through its Application to Sharks. London.

Li, Y., Zhang, Y., Hussey, N.E., and Dai, X. 2016. Urea and lipid extraction treatment effects on $\delta 15 \mathrm{~N}$ and $\delta 13 \mathrm{C}$ values in pelagic sharks. Rapid Commun. Mass Spectrom. 30:18. https://doi.org/10.1002/rcm.7396.

Liu, K.-K., and Kaplan, I.R. 1989. The eastern tropical Pacific as a source of $15 \mathrm{~N}$-enriched nitrate in seawater off southern California. Limnol. Oceanogr. 34:820-830.

https://doi.org/10.4319/lo.1989.34.5.0820.

Loor-andrade, P., Galván-magaña, F., Elorriaga-Verplancken, F.R., Polo-Silva, C., and Delgado-huertas, A. 2015. Population and individual foraging patterns of two hammerhead sharks using carbon and nitrogen stable isotopes. Rapid Commun. Mass Spectrom. 29:821829. https://doi.org/10.1002/rcm.7169.

Lysy, M., Stasko, A.D., and Swanson, H.K. 2014. nicheROVER: (Niche) (R)egion and Niche (Over)lap Metrics for Multidimensional Ecological Niches (Version 1.0). https://rdrr.io/cran/nicheROVER/ Visited: 5/12/2020.

Malzahn, A.M., Aberle, N., Clemmesen, C., and Boersma, M. 2007. Nutrient limitation of primary producers affects planktivorous fish condition. Limnol. Oceanogr. 52:2062-2071.

Mason, J.G., Alfaro-shigueto, J., Mangel, J.C., Crowder, L.B., and Ardoin, N.M. 2020. Fishers' solutions for hammerhead shark conservation in Peru. Biol. Conserv. 243:108460. https://doi.org/10.1016/j.biocon.2020.108460.

Mcardle, B.H., Anderson, M.J., Ecology, S., and Jan, N. 2001. Fitting Multivariate Models to Community Data : A Comment on Distance-Based Redundancy Analysis. Ecol. Soc. Am. 82:290-297.

McGill, B.J., Enquist, B.J., Weiher, E., and Westoby, M. 2006. Rebuilding community ecology from functional traits. Trends Ecol. Evol. 21:178-185. https://doi.org/10.1016/j.tree.2006.02.002.

Meyer, L., Pethybridge, H.R., Nichols, P.D., Beckmann, C., and Huveneers, C. 2019. 
602

603

604

605

606

607

608

609

610

611

612

613

614

615

616

617

618

619

620

621

622

623

624

625

626

627

628

629

630

631

632

633

634

635

636

637

638

639

640

641

642
Abiotic and biotic drivers of fatty acid tracers in ecology: A global analysis of chondrichthyan profiles. Funct. Ecol. 33:1243-1255. https://doi.org/10.1111/13652435.13328 .

Morales, M. del C., Cerpa, L.C., Cornejo, T.S., Coaquira, F.P., Mamani, Y.P., de la Cruz, Y. de la C., and Arriola, D.A. 2019. Estudios de Geología Marina en el Perú. Lima. INGEMMET. 106 pp.

Newsome, S.D., Martinez del Rio, C., Bearhop, S., and Phillips, D.L. 2007. A niche for isotopic ecology. Front. Ecol. Environ. 5:429-436. https://doi.org/10.1890/060150.01.

Olin, J.A., Hussey, N.E., Fritts, M., Heupel, M.R., Simpfendorfer, C.A., Poulakis, G.R., and Fisk, A.T. 2011. Maternal meddling in neonatal sharks: Implications for interpreting stable isotopes in young animals. Rapid Commun. Mass Spectrom. 25:1008-1016.

https://doi.org/10.1002/rcm.4946.

Paulmier, A., and Ruiz-Pino, D. 2009. Oxygen minimum zones (OMZs) in the modern ocean. Prog. Oceanogr. 80:113-128. https://doi.org/10.1016/j.pocean.2008.08.001.

Pethybridge, H., Daley, R., Virtue, P., and Nichols, P. 2010. Lipid composition and partitioning of deepwater chondrichthyans: inferences of feeding ecology and distribution. Mar. Biol. 157:1367-1384. https://doi.org/10.1007/s00227-010-1416-6.

Phleger, C.F., Nelson, M.M., Mooney, B.D., Nichols, P.D., Ritar, A.J., Smith, G.G., Hart, P.R., and Jeffs, A.G. 2001. Lipids and nutrition of the southern rock lobster, Jasus edwardsii, from hatch to puerulus. Mar. Freshw. Res. 52:1475-1486.

Potapov, A.M., Tiunov, A. V, and Scheu, S. 2018. Uncovering trophic positions and food resources of soil animals using bulk natural stable isotope composition. Biol. Rev. 94:3759. https://doi.org/10.1111/brv.12434.

Quezada-Romegialli, C., Jackson, A.L., Hayden, B., Kahilainen, K.K., Lopes, C., and Harrod, C. 2018. tRophicPosition, an r package for the Bayesian estimation of trophic position from consumer stable isotope ratios. Methods Ecol. Evol. 9:1592-1599. https://doi.org/10.1111/2041-210X.13009.

Rabehagasoa, N., Lorrain, A., Bach, P., Potier, M., Jaquemet, S., Richard, P., and Ménard, F. 2012. Isotopic niches of the blue shark Prionace glauca and the silky shark Carcharhinus falciformis in the southwestern Indian Ocean. Endanger. Species Res. 17:83-92. https://doi.org/10.3354/esr00418. 
643

662

663

664

665

666

667

668

669

670

671

672

673

674

675

676

677

678

679

680

681

682

683

684
Rigby, C.L., Barreto, R., Carlson, J., Fernando, D., Fordham, S., Herman, K., Jabado, R.W., Liu, K.M., Marshall, A., Pacoureau, N., Romanov, E., Sherley, R.B., and Winker, H. 2019. Smooth Hammerhead ( Sphyrna zygaena ). IUCN Red List Threat. Species 2019 8235:e.T39388A2921825.

Rohner, C.A., Couturier, L.I.E., Richardson, A.J., Pierce, S.J., Prebble, C.E.M., Gibbons, M.J., and Nichols, P.D. 2013. Diet of whale sharks Rhincodon typus inferred from stomach content and signature fatty acid analyses. Mar. Ecol. Prog. Ser. 493:219-235. https://doi.org/10.3354/meps10500.

Rosende-Pereiro, A., Flores-Ortega, J.R., González-Sansón, G., and Corgos, A. 2020. Stomach content and stable isotopes reveal an ontogenetic dietary shift of young-of-the-year scalloped hammerhead sharks (Sphyrna lewini) inhabiting coastal nursery areas. Environ. Biol. Fishes 103:49-65. https://doi.org/10.1007/s10641-019-00932-0.

Saito, H., Ishihara, K., and Murase, T. 1997. The fatty acid composition in tuna (bonito, Euthynnus pelamis) caught at three different localities from tropics to temperate. J. Sci. Food Agric. 73:53-59. https://doi.org/10.1002/(SICI)1097-0010(199701)73:1<53::AIDJSFA707>3.0.CO;2-5.

Sarakinos, H.C., Johnson, M.L., and Vander Zanden, M.J. 2002. A synthesis of tissuepreservation effects on carbon and nitrogen stable isotope signatures. Can. J. Zool. 80:381387. https://doi.org/10.1139/z02-007.

Schoener, T.W. 1968. The Anolis Lizards of Bimini : Resource Partitioning in a Complex Fauna Author ( s ): Thomas W. Schoener Published by: Wiley Stable URL: http://www.jstor.org/stable/1935534 REFERENCES Linked references are available on JSTOR for this article : You may. Ecol. Soc. Am. 49:704-726.

Semeniuk, C.A.D., Speers-Roesch, B., and Rothley, K.D. 2007. Using fatty-acid profile analysis as an ecologic indicator in the management of tourist impacts on marine wildlife: A case of stingray-feeding in the Caribbean. Environ. Manage. 40:665-677.

https://doi.org/10.1007/s00267-006-0321-8.

Shannon, C.E. 1948. A Mathematical Theory of Communication. Bell Syst. Tech. J. 27:623-656. https://doi.org/10.1002/j.1538-7305.1948.tb00917.x.

Shipley, O.N., Murchie, K.J., Frisk, M.G., Shea, O.R.O., Winchester, M.M., Brooks, E.J., Pearson, J., and Power, M. 2018. Trophic niche dynamics of three nearshore benthic predators in The Bahamas. Hydrobiologia 813:177-188. https://doi.org/10.1007/s10750018-3523-1. 
685

686

687

688

689

690

691

692

693

694

695

696

697

698

699

700

701

702

703

704

705

706

707

708

709

710

711

712

713

714

715

716

717

718

719

720

721

722

723

724

725

726
Simpfendorfer, C.A., and Milward, N.E. 1993. Utilisation of a tropical bay as a nursery area by sharks of the families Carcharhinidae and Sphyrnidae. Environ. Biol. Fishes 37:337-345. https://doi.org/10.1007/BF00005200.

Smale, M.J. 1991. Occurrence and feeding of three shark species, Carcharhinus brachyurus, C. obscurus and Sphyrna zygaena, on the Eastern Cape coast of South Africa. South African J. Mar. Sci. 11:31-42.

Spalding, M.D., Fox, H.E., Allen, G.R., Davidson, N., Ferdaña, Z.A., Finlayson, M.A.X., Halpern, B.S., Jorge, M.A., Lombana, A., Lourie, S.A., Martin, K.D., Mcmanus, E., Molnar, J., Recchia, C.A., and Robertson, J. 2007. Marine Ecoregions of the World : A Bioregionalization of Coastal and Shelf Areas. Bioscience 57:573-583.

Swanson, H.K., Lysy, M., Power, M., Stasko, A.D., Johnson, J.D., and Reist, J.D. 2015. A new probabilistic method for quantifying n-dimensional ecological niches and niche overlap. Ecology 96:318-324.

Sweeting, C.J., Polunin, N.V.C., and Jennings, S. 2006. Effects of chemical lipid extraction and arithmetic lipid correction on stable isotope ratios of fish tissues. Rapid Commun. Mass Spectrom. 20:595-601. https://doi.org/10.1002/rcm.2347.

Turner, J.P., and Rooker, J.R. 2005. Effect of diet on fatty acid compositions in Sciaenops ocellatus. J. Fish Biol. 67:1119-1138. https://doi.org/10.1111/j.0022-1112.2005.00816.x.

Urzúa, Á., and Anger, K. 2011. Larval biomass and chemical composition at hatching in two geographically isolated clades of the shrimp Macrobrachium amazonicum: Intra- or interspecific variation? Invertebr. Reprod. Dev. 55:236-246.

https://doi.org/10.1080/07924259.2011.576155.

Urzúa, Á., and Anger, K. 2013. Seasonal variations in larval biomass and biochemical composition of brown shrimp, Crangon crangon (Decapoda, Caridea), at hatching. Helgol. Mar. Res. 67:267-277. https://doi.org/10.1007/s10152-012-0321-4.

Vooren, C.M., Klippel, S., and Galina, A.B. 2005. Biologia e status de conservação dos tubarões martelo Sphyrna lewini e S. zygaena. In Ações para a Conserv. tubarões e raias no sul do Bras. (Vooren, C.M., and S. Klippel, eds). p. 262. Igaré, Porto Alegre., 1st ed.

Wai, T.-C., Leung, K.M.Y., Sin, S.Y.T., Cornish, A., Dudgeon, D., and Williams, G.A. 2011. Spatial, seasonal, and ontogenetic variations in the significance of detrital pathways and terrestrial carbon for a benthic shark, Chiloscyllium plagiosum (Hemiscylliidae), in a tropical estuary. Limnol. Oceanogr. 56:1035-1053.

https://doi.org/10.4319/lo.2011.56.3.1035. 
727

728

729

730

731

732

733

734

735

736

737

738
Wai, T.-C., Yeung, J.W.Y., Lam, V.Y.Y., Leung, K.M.Y., Dudgeon, D., and Williams, G.A. 2012. Monsoons and habitat influence trophic pathways and the importance of terrestrial-marine linkages for estuary sharks. Ecosphere 3:art8. https://doi.org/10.1890/es11-00276.1.

Xu, J., Yang, Q., Zhang, M., Zhang, M., Xie, P., and Hansson, L.-A. 2011. Preservation effects on stable isotope ratios and consequences for the reconstruction of energetic pathways. Aquat. Ecol. 45:483-492. https://doi.org/10.1007/s10452-011-9369-5. 
Figure 1

Landing ports (dots) and nursery areas smooth hammerhead Sphyrna zygaena (polygons).

Areas were delimitated based on points of presence of juveniles Smooth Hammerhead from catches by artisanal fishery. Data source: ProDelphinus 


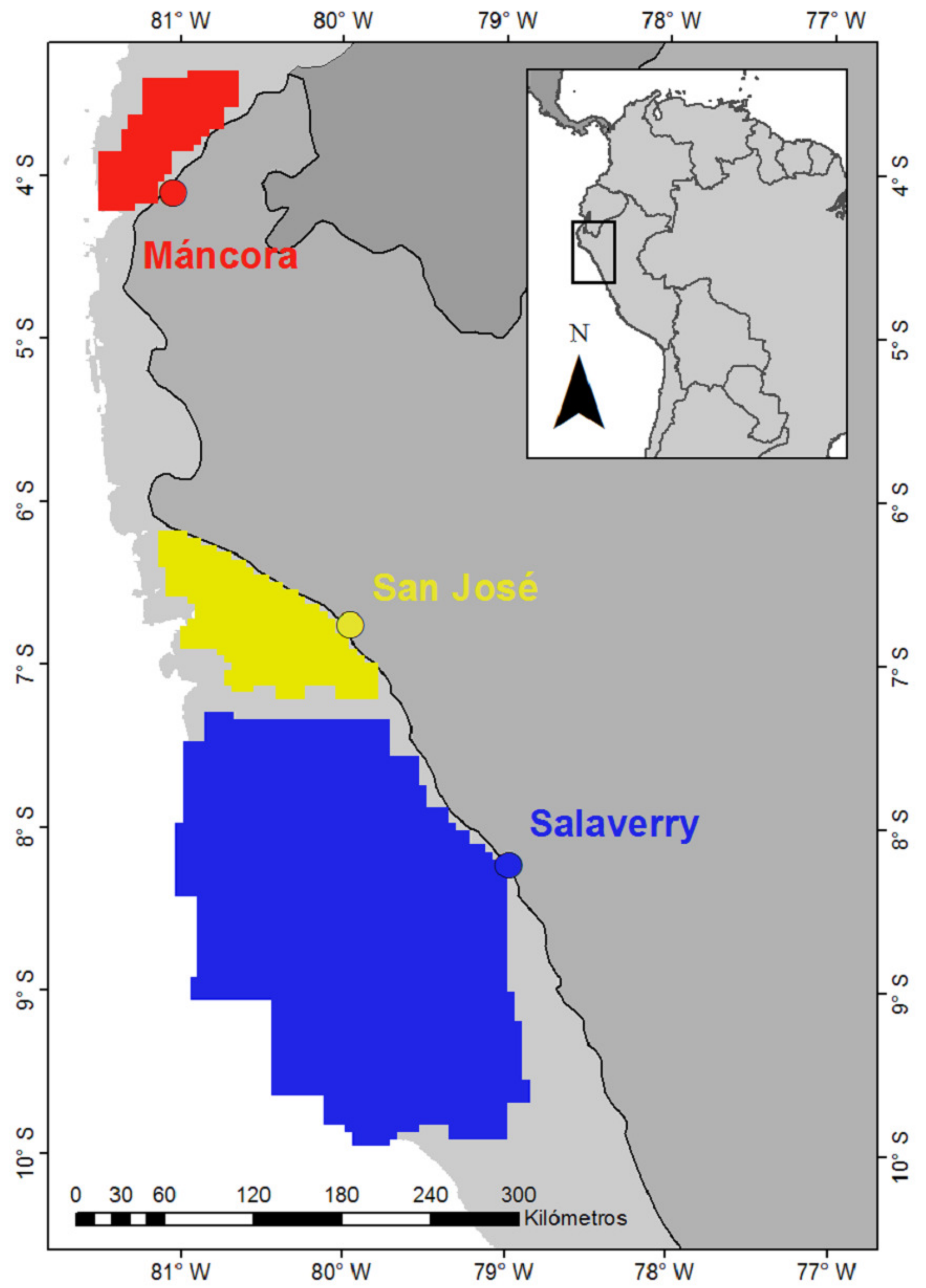


Figure 2

Mean and standard deviation of the $\delta^{13} \mathrm{C}$ and $\delta^{15} \mathrm{~N}$ of smooth hammerhead Sphyrna zygaena by nursery area and tissue type.

Results for muscle tissue are represented by squares and results for liver tissue are represented by triangles. Máncora, red; San José, yellow; Salaverry, blue. 


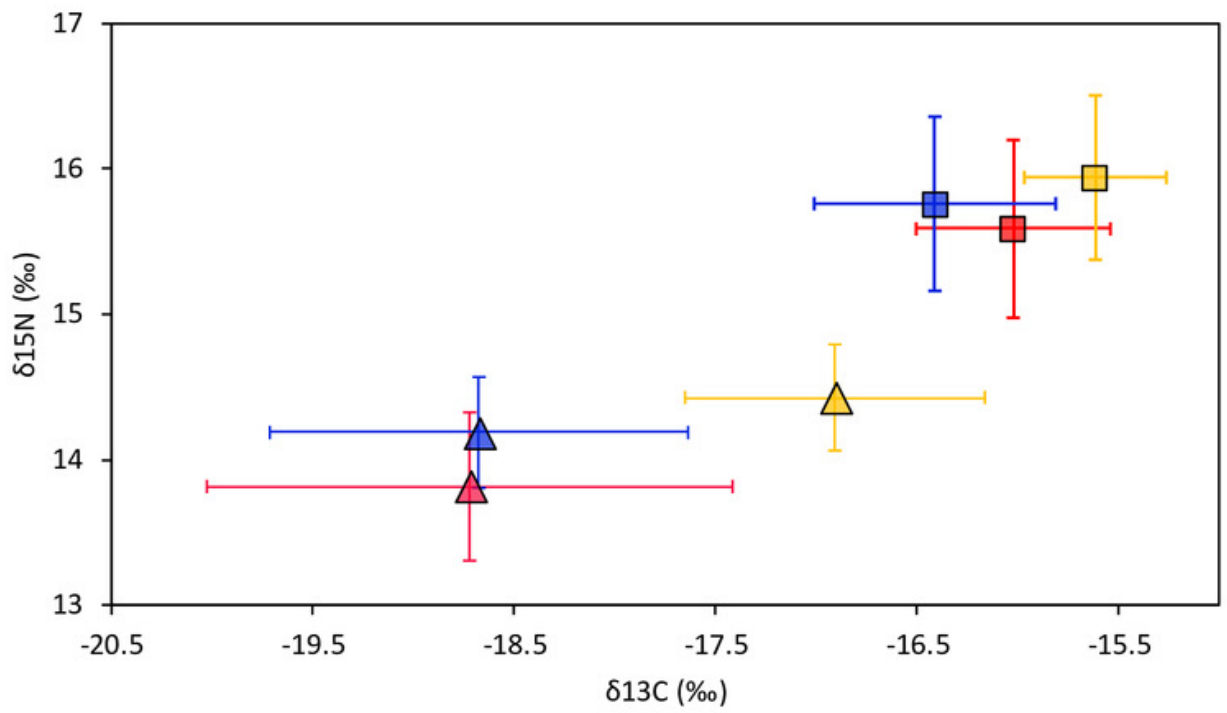


Figure 3

Four elliptical projections of the niche region $\left(\mathrm{N}_{\mathrm{R}}\right)$ of smooth hammerhead Sphyrna zygaena muscle (a) and liver (b) tissue from each nursery area.

Máncora, red; San José, yellow; Salaverry, blue. 
$\delta^{15} \mathrm{~N}$

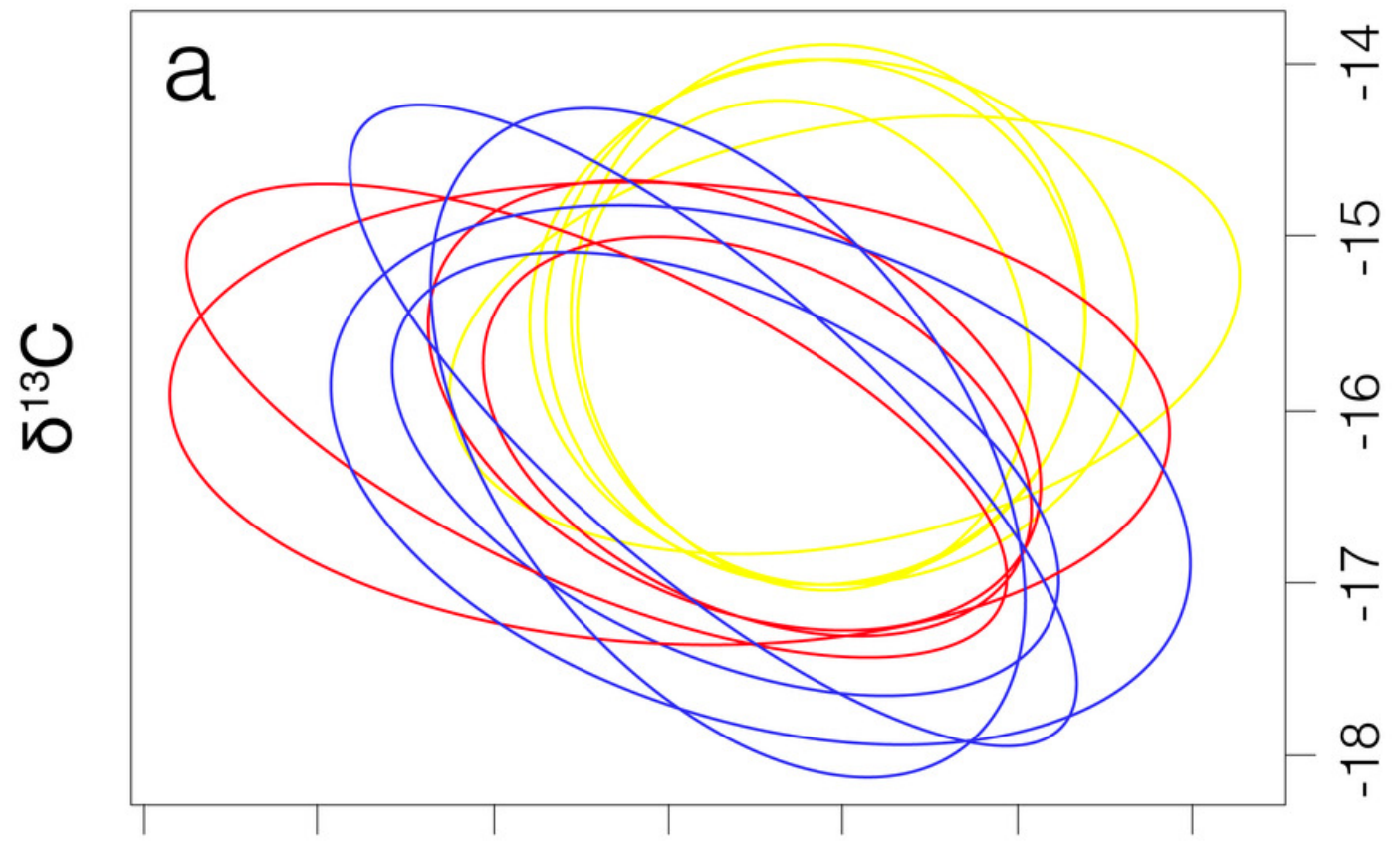

$\begin{array}{lllllll}14.0 & 14.5 & 15.0 & 15.5 & 16.0 & 16.5 & 17.0\end{array}$

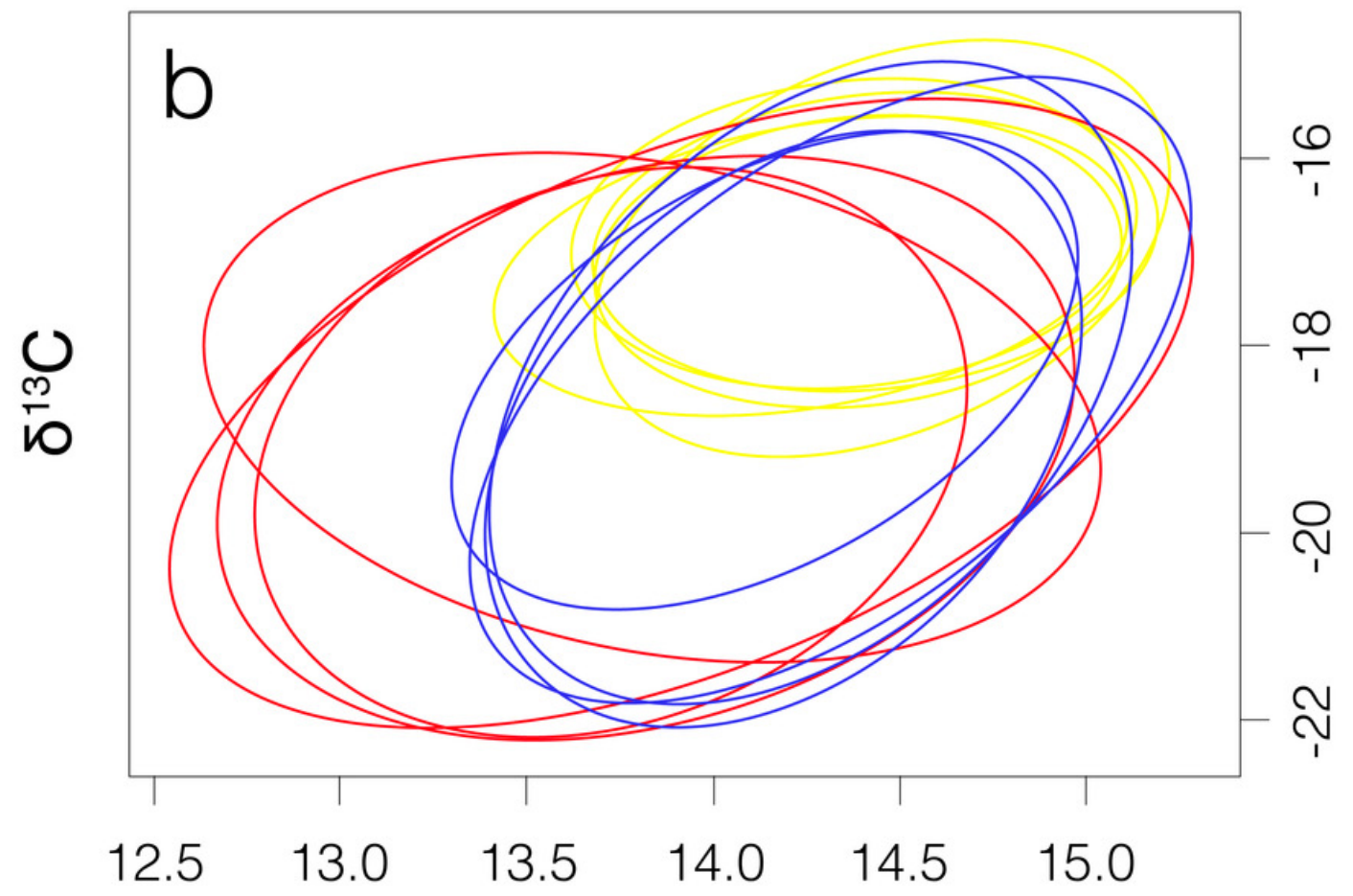




\section{Figure 4}

Mean and standard deviation of the $\delta^{13} \mathrm{C}$ and $\delta^{15} \mathrm{~N}$ of sympatric species and scatterplot of the liver tissue $\delta^{13} \mathrm{C}$ and $\delta^{15} \mathrm{~N}$ of the smooth hammerhead Sphyrna zygaena from each nursery area.

A: Máncora; B: San José; C: Salaverry; Eastern Pacific bonito (Sarda chiliensis); Spinetail mobula (Mobula japanica); Jumbo squid (Dosidicus gigas); Anchoveta (Engraulis ringens); South Pacific hake (Merluccius gayi); Minor stardrum (Stellifer minor); Drab tonguefish (Symphurus melanurus); Peruvian weakfish (Cynoscion analis); Suco croaker (Paralonchurus dumerilii); Grey mullet (Mugil cephalus); Pacific menhaden (Ethmidium maculatum); Peruvian morwong (Cheilodactylus variegatus); Point-Tuza croaker (Ophioscion scierus); Paloma pompano (Trachinotus paitensis); Longnose anchovy (Anchoa nasus). 


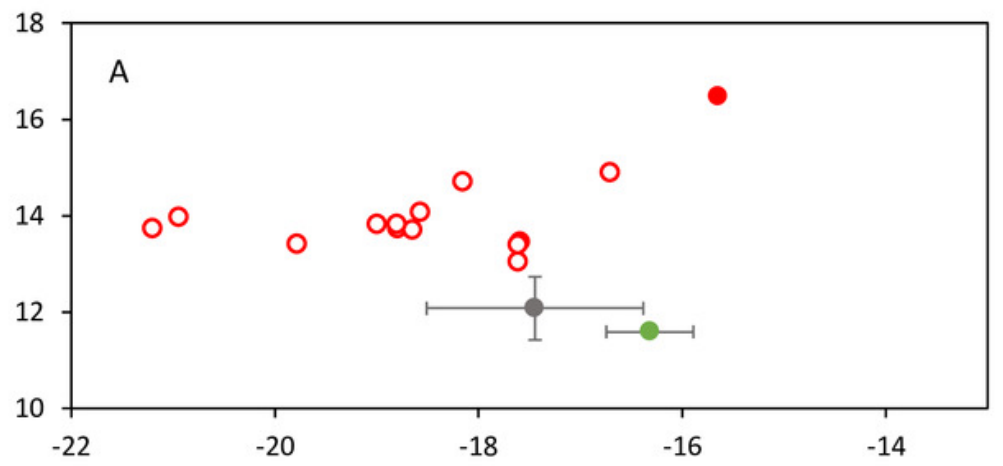

- Striped bonito

- Spinetail mobula

- Jumbo squid

O Hammerhead

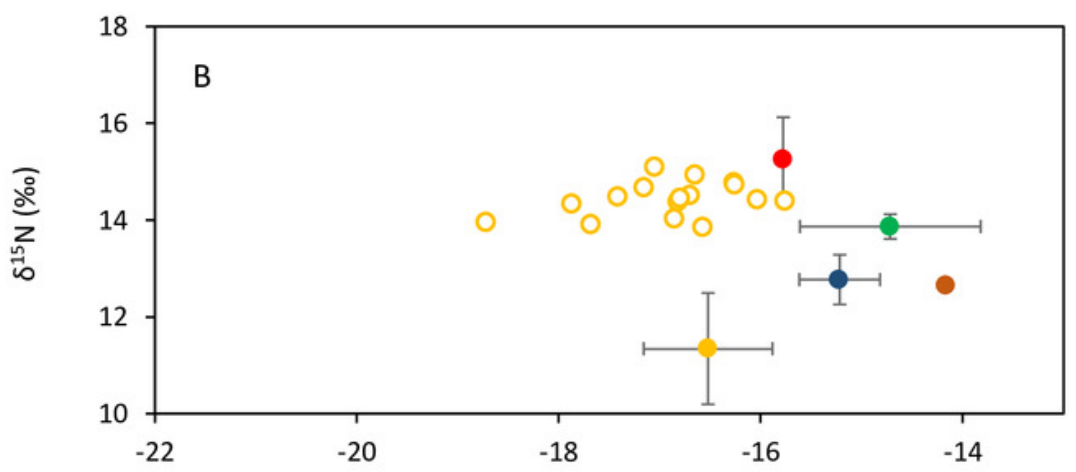

- Peruvian anchovy

- Striped bonito

- South Pacific Hake

- Minor stardrum

- Drab tonguefish

- Hammerhead

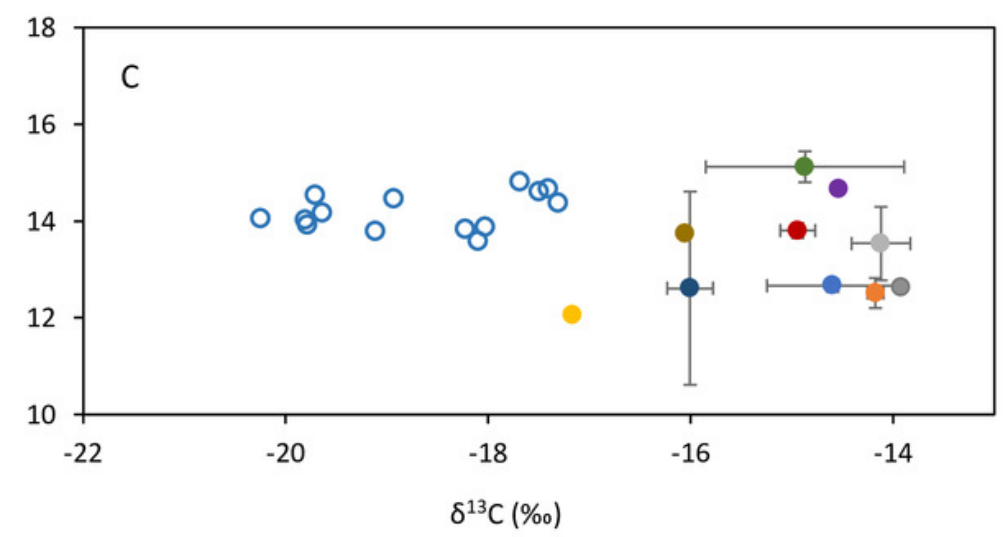

- Peruvian anchovy

- Peruvian weakfish

- Suco croaker

- Flathead grey mullet

- Pacific menhaden

- South Pacific Hake

- Peruvian morwong

- Point-tuza croaker

- Paloma pompano

- Longnose anchovy

O Hammerhead 
Figure 5

Principal Coordinate Ordination (PCO) based on $\delta^{13} \mathrm{C}$ and $\delta^{15} \mathrm{~N}$ and fatty acid profiles of muscle (A) and liver (B) tissue of smooth hammerhead Sphyrna zygaena from each nursery area.

Máncora (red), San José (yellow) and Salaverry (blue). Vectors show variables with Pearson correlation $\geq 0.5$. 

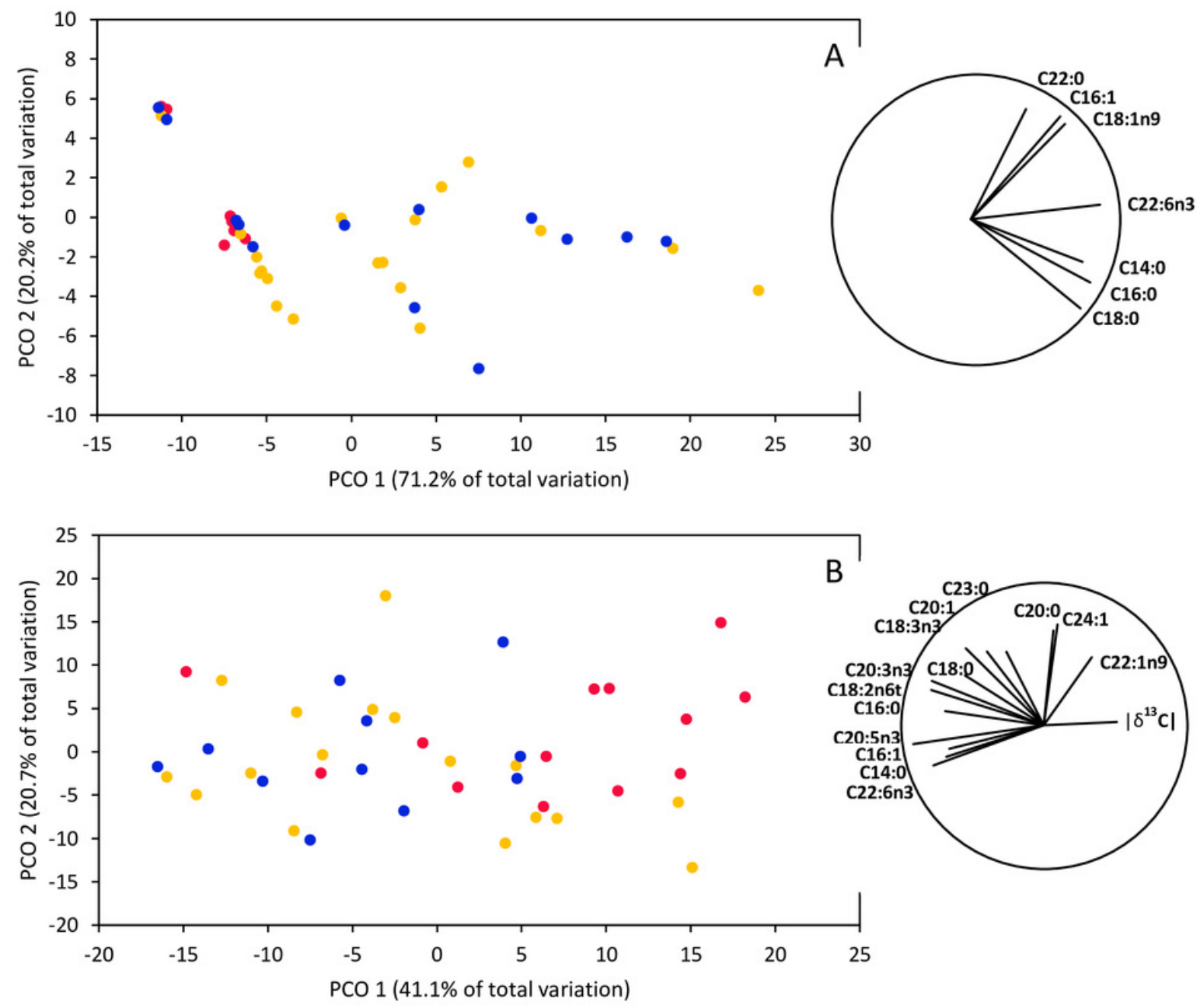


\section{Table $\mathbf{1}$ (on next page)}

Mean niche size $\left(\mathrm{N}_{\mathrm{S}}\right)$ and niche overlap based on $\delta^{13} \mathrm{C}$ and $\delta^{15} \mathrm{~N}$ of muscle and liver tissues of smooth hammerhead Sphyrna zygaena from the three nursery areas. 
1

2

3

4

5

6

\begin{tabular}{|c|c|c|c|c|c|}
\hline & & Máncora & San José & Salaverry & $\mathbf{N}_{\mathbf{S}}$ \\
\hline \multirow{3}{*}{$\frac{0}{\circlearrowright}$} & Máncora & - & 71.39 & 74.31 & 5.23 \\
\hline & San José & 69.92 & - & 87.27 & 3.75 \\
\hline & Salaverry & 62.37 & 84.26 & - & 3.43 \\
\hline \multirow{3}{*}{ 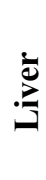 } & Máncora & - & 67.35 & 75.02 & 12.57 \\
\hline & San José & 70.28 & - & 88.91 & 4.82 \\
\hline & Salaverry & 64.71 & 82.91 & - & 7.13 \\
\hline
\end{tabular}

7

8 


\section{Table 2 (on next page)}

Muscle and liver fatty acid concentrations and Shannon fatty acid diversity of the smooth hammerhead Sphyrna zygaena in each nursery area.

Mean \pm standard deviation in $\mathrm{mg} \mathrm{g} \mathrm{PS}^{-1}$. SFA: saturated fatty acids; MUFA: monounsaturated fatty acids; PUFA: polyunsaturated fatty acids; TFA: total fatty acids. 
1

\begin{tabular}{|c|c|c|c|c|c|c|}
\hline & \multicolumn{3}{|c|}{ Muscle } & \multicolumn{3}{|c|}{ Liver } \\
\hline & Máncora & San José & Salaverry & Máncora & San José & Salaverry \\
\hline C11:0 & nd & $0.03 \pm 0.1$ & $0.05 \pm 0.2$ & $0.05 \pm 0.2$ & $0.04 \pm 0.2$ & nd \\
\hline $\mathrm{C} 12: 0$ & nd & nd & nd & $0.06 \pm 0.2$ & $0.08 \pm 0.2$ & nd \\
\hline $\mathrm{C} 13: 0$ & nd & nd & nd & $0.04 \pm 0.2$ & $0.05 \pm 0.2$ & nd \\
\hline $\mathrm{C} 14: 0$ & nd & $0.11 \pm 0.3$ & $0.31 \pm 0.4$ & $7.77 \pm 2.1^{\mathbf{a}}$ & $12.86 \pm 4.7^{\mathbf{b}}$ & $14.08 \pm 4.6^{\mathbf{b}}$ \\
\hline $\mathrm{C} 15: 0$ & nd & nd & nd & $1.9 \pm 0.5^{\mathbf{a}}$ & $2.25 \pm 0.7^{\mathbf{a}, \mathbf{b}}$ & $2.14 \pm 0.4^{\mathbf{b}}$ \\
\hline $\mathrm{C} 16: 0$ & $1.35 \pm 0.2^{\mathbf{a}}$ & $2.40 \pm 0.9^{\mathbf{b}}$ & $2.22 \pm 1.0^{\mathbf{b}}$ & $82.3 \pm 18.8^{\mathbf{a}}$ & $88.6 \pm 25.9^{\mathbf{b}}$ & $91.36 \pm 22.2^{\mathbf{b}}$ \\
\hline $\mathrm{C} 17: 0$ & nd & nd & nd & $4.11 \pm 0.8^{\mathbf{a}}$ & $4.14 \pm 1^{\mathbf{a}}$ & $5.71 \pm 0.1^{\mathbf{b}}$ \\
\hline C18:0 & $0.60 \pm 0.4^{\mathbf{a}}$ & $1.59 \pm 0.7^{\mathbf{b}}$ & $1.23 \pm 0.9^{\mathbf{a}, \mathbf{b}}$ & $23.9 \pm 2.5^{\mathbf{a}}$ & $27.67 \pm 5.5^{\mathbf{a}, \mathbf{b}}$ & $29.6 \pm 5.1^{\mathbf{b}}$ \\
\hline $\mathrm{C} 20: 0$ & nd & nd & nd & $0.24 \pm 0.5$ & $0.14 \pm 0.4$ & $0.18 \pm 0.6$ \\
\hline $\mathrm{C} 22: 0$ & nd & nd & $0.33 \pm 0.9$ & nd & $0.39 \pm 1.6$ & $1.32 \pm 3.7$ \\
\hline $\mathrm{C} 23: 0$ & nd & nd & nd & $0.69 \pm 1.7$ & $2.01 \pm 3.8$ & nd \\
\hline $\mathrm{C} 24: 0$ & nd & nd & nd & nd & $0.08 \pm 0.3$ & $0.08 \pm 0.3$ \\
\hline TOTAL SFA & $1.95 \pm 0.6^{\mathrm{a}}$ & $4.12 \pm 1.7^{b}$ & $4.14 \pm 2.2^{b}$ & $121.1 \pm 22.5$ & $138.3 \pm 37.5$ & $143.9 \pm 29.3$ \\
\hline $\mathrm{C} 14: 1$ & nd & nd & nd & $0.13 \pm 0.5$ & $0.05 \pm 0.2$ & nd \\
\hline C16:1 & nd & $0.09 \pm 0.3$ & $0.28 \pm 0.6$ & $17.7 \pm 14.1$ & $27 \pm 13.3$ & $23.54 \pm 7.6$ \\
\hline $\mathrm{C} 17: 1$ & nd & nd & nd & $0.48 \pm 1$ & $0.68 \pm 1.4$ & nd \\
\hline C18:1n9 & nd & $1.03 \pm 1.1$ & $0.98 \pm 1.1$ & $44.63 \pm 19.4$ & $41.18 \pm 14.4$ & $48.81 \pm 20.5$ \\
\hline $\mathrm{C} 20: 1$ & nd & nd & nd & $5.35 \pm 4.9^{\mathbf{a}}$ & $3.39 \pm 3.2^{\mathbf{b}}$ & $7.97 \pm 5.6^{\mathbf{a}, \mathbf{b}}$ \\
\hline
\end{tabular}




\begin{tabular}{|c|c|c|c|c|c|c|}
\hline $\mathrm{C} 22: \ln 9$ & nd & nd & nd & $0.26 \pm 0.7$ & nd & $0.26 \pm 0.8$ \\
\hline $\mathrm{C} 24: 1$ & nd & nd & nd & $1.11 \pm 1.3$ & $1.46 \pm 1.8$ & $0.23 \pm 1$ \\
\hline TOTAL MUFA & nd & $1.12 \pm 1.3$ & $1.26 \pm 1.5$ & $69.7 \pm 33.6$ & $73.8 \pm 29$ & $80.8 \pm 25.1$ \\
\hline $\mathrm{C} 18: 3 \mathrm{n} 3$ & nd & nd & nd & $0.94 \pm 1.5$ & $1.09 \pm 1.5$ & $1.1 \pm 1.5$ \\
\hline $\mathrm{C} 20: 3 \mathrm{n} 3$ & nd & nd & nd & $1.57 \pm 3.4$ & $2.83 \pm 3.5$ & $2.07 \pm 3.5$ \\
\hline $\mathrm{C} 20: 5 \mathrm{n} 3$ & nd & $0.08 \pm 0.3$ & nd & $11.32 \pm 18.9$ & $20.97 \pm 25.1$ & $33.74 \pm 25.6$ \\
\hline $\mathrm{C} 22: 6 \mathrm{n} 3$ & nd & $0.94 \pm 1.8$ & $1.41 \pm 1.8$ & $11.07 \pm 14.2^{\mathbf{a}}$ & $52.12 \pm 41.2^{\mathbf{b}}$ & $42.99 \pm 43.5^{\mathbf{a}, \mathbf{b}}$ \\
\hline TOTAL PUFAn3 & nd & $1.02 \pm 2.1$ & $1.41 \pm 1.8$ & $24.9 \pm 35.4^{\mathrm{a}}$ & $77 \pm 63.4^{b}$ & $79.9 \pm 61.1^{b}$ \\
\hline $\mathrm{C} 18: 2 \mathrm{n} 6 \mathrm{c}$ & nd & nd & nd & nd & $0.28 \pm 0.8$ & nd \\
\hline $\mathrm{C} 18: 2 \mathrm{n} 6 \mathrm{t}$ & nd & nd & nd & $1.21 \pm 1.9^{\mathbf{a}}$ & $2.1 \pm 2.1^{\mathbf{a}, \mathbf{b}}$ & $3.55 \pm 2.3^{\mathbf{b}}$ \\
\hline C18:3n6 & nd & nd & nd & $0.2 \pm 0.7$ & $0.62 \pm 1.1$ & nd \\
\hline C20:3n6 & nd & nd & nd & nd & $0.05 \pm 0.2$ & nd \\
\hline TOTAL PUFAn6 & nd & nd & nd & $1.4 \pm 2.5^{\mathrm{a}}$ & $3.1 \pm 3.5^{b}$ & $3.5 \pm 2.3^{b}$ \\
\hline $\mathrm{C} 20: 2$ & nd & nd & nd & $0.2 \pm 0.7$ & $0.26 \pm 0.7$ & nd \\
\hline TOTAL PUFA & nd & $1.02 \pm 2.1$ & $1.41 \pm 1.8$ & $26.5 \pm 38$ & $80.3 \pm 64.1$ & $83.4 \pm 62.2$ \\
\hline TOTAL FAs & $1.95 \pm 0.6^{\mathrm{a}}$ & $6.26 \pm 4.5^{b}$ & $6.82 \pm 4.6^{b}$ & $217.2 \pm 70.1^{\mathrm{a}}$ & $292.4 \pm 98.8^{b}$ & $308.1 \pm 90.4^{b}$ \\
\hline Shannon's Index & $0.46 \pm 0.32^{\mathrm{a}}$ & $0.99 \pm 0.43^{b}$ & $1.05 \pm \mathbf{0 . 5 8}^{\mathrm{b}}$ & $1.76 \pm 0.21^{\mathrm{a}}$ & $1.93 \pm 0.19^{b}$ & $1.92 \pm 0.1^{b}$ \\
\hline
\end{tabular}

2 